\title{
Dissolved organic nitrogen: an important source of nitrogen for the microphytobenthos in sandy sediment
}

\author{
Kristina Sundbäck ${ }^{1, *}$, Elin Lindehoff ${ }^{2,3}$, Edna Granéli ${ }^{2}$ \\ ${ }^{1}$ Department of Marine Ecology, University of Gothenburg, 40530 Gothenburg, Sweden \\ ${ }^{2}$ Linnaeus University, Marine Ecology Department, 39182 Kalmar, Sweden \\ ${ }^{3}$ Present address: Umeå Marine Science Centre, 91020 Hörnefors, Sweden
}

\begin{abstract}
To test the hypothesis that dissolved organic nitrogen (DON) is important for sustaining primary production by the microphytobenthos (MPB) in nitrogen-limited conditions, we measured the uptake of ${ }^{15} \mathrm{~N}$-labelled urea, the amino acids glycine (GLY) and glutamic acid (GLU), and nitrate and ammonium under simulated in situ light and temperature conditions. Microphytobenthic primary production and chlorophyll a $(\mathrm{chl}$ a) were also measured. The MPB was dominated by diatoms attached to sand grains, with cyanobacteria making up $30 \%$ of the biomass. Activities of the hydrolytic ectoenzymes leucine aminopeptidase (AMA), alkaline phosphatase (APA) and $\beta$-glucosidase (GLA) in filter-fractionated sediment showed that the microbenthic community was strongly deficient in nitrogen $(\mathrm{N})$, with the bacterial fraction $(<1 \mu \mathrm{m})$ also limited in phosphorus. Uptake of DON (urea + GLU + GLY) accounted for $~ 50$ to $65 \%$ of the uptake of ${ }^{15} \mathrm{~N}$-labelled substrates, with a higher proportion of DON uptake at low substrate concentrations $(\leq 2 \mu \mathrm{M})$. Except for nitrate, the kinetics fitted a linear model. The calculated relative preference index (RPI), based on pore water concentrations, suggested that the order of preference of the microbenthic community was $\mathrm{NH}_{4}{ }^{+}>$ urea $>$ GLU $>\mathrm{NO}_{3}^{-}>$GLY. Using a prokaryotic inhibitor (chloramphenicol), and theoretical calculations of algal uptake based on C:chl a ratios, it was estimated that the 'algal' uptake of nitrogen accounted for $\sim 55$ to $90 \%$ of DON uptake. Uptake rates were, however, estimated to cover only 26 to $50 \%$ of the nitrogen demand of the MPB, suggesting that pore water concentrations of nitrogen were not sufficient to meet the microalgal demand in early summer and that, in sandy sediments of microtidal waters, the MPB may often be severely limited in nitrogen.
\end{abstract}

KEY WORDS: Microphytobenthos $\cdot$ Nitrogen $\cdot$ DON $\cdot$ Urea $\cdot$ Amino acids $\cdot$ Ectoenzymes

\section{INTRODUCTION}

In shallow-water photic sediments, benthic microalgae-the microphytobenthos (MPB) - are important primary producers (Underwood \& Kromkamp 1999). They also play a key role in regulating benthic nutrient cycling and the flux of nutrients out of the sediment (McGlathery et al. 2007 and references therein). By producing oxygen, and competing with bacteria for nitrogen, the MPB also regulates bacterial processes such as denitrification and nitrification (RisgaardPetersen 2003 and references therein). As nutrient concentrations in sediment pore waters are generally higher than those in the overlying water, it has often been assumed that the MPB cannot be nutrient limited, especially in muddy, intertidal sediments where the organic content, and hence mineralization rate, is high. There is, however, accumulating evidence from different types of shallow-water ecosystem that the MPB may be nutrient limited, often turning sediments into nutrient sinks (e.g. Nilsson et al. 1991, Rizzo et al. 1996, Cerco \& Seitzinger 1997, Thornton et al. 2002, Eyre \& Ferguson 2005). The major importance of benthic microalgae for sediment biogeochemical cycles has also been recently illustrated by modelling approaches (Cook et al. 2009, Hochard et al. 2010). 
As is the case for tropical sandy areas, which are extremely limited in nitrogen (Eyre et al. 2008), a strong influence of the MPB on benthic turnover of nitrogen also appears to apply to sandy sediments in cool nitrogen-poor microtidal areas (Sundbäck \& Miles 2000, Sundbäck et al. 2006, Engelsen et al. 2008). Although microalgae are apparently N-limited in such sediments, the MPB biomass and primary production are often as high — or even higher - than in relatively nutrient-rich silty sediments (Miles \& Sundbäck 2000, Engelsen et al. 2008). This is also the case for sandy sediments on tidal coasts (Barranguet et al. 1998, Billerbeck et al. 2007). Explanations for a higher algal activity in sandy sediments include better light penetration and more effective transport of solute to the algae, particularly in permeable intertidal inundated sediments (Billerbeck et al. 2007). An additional explanation is that $\mathrm{N}$ is efficiently recycled within the microbial communities of the sediment surface (Lomstein et al. 1998, Cook et al. 2007, Veuger et al. 2007, Gribsholt et al. 2009), sustaining productivity by using available 'old nitrogen'. This implies that not only ammonium, but also labile fractions of dissolved organic nitrogen (DON), such as urea and dissolved free amino acids (DFAA), could be important sources of $\mathrm{N}$ when levels of dissolved inorganic nitrogen (DIN) are low. Moreover, the more autotrophic the sediment the greater may be the relative importance of DON (Cook et al. 2009). The observation of high fluxes of DON into shallow-water sediments supports this idea (Tyler et al. 2003, Cook et al. 2004, Sundbäck et al. 2004, 2006). It could be assumed that most of this uptake is due to bacteria because of their high metabolic activity (Fenchel et al. 2000). However, simultaneous measurements of the uptake of DON by algae and bacteria have shown that algal uptake may dominate in the photic zone of the sediment (Veuger \& Middelburg 2007). Therefore, benthic microalgae may control benthic fluxes of DON, as well as DIN (Tyler et al. 2003).

Today, it is well documented-at least for plankton communities - that many microalgal species utilize DON fractions (reviews by Antia et al. 1991, Glibert et al. 2006, Bronk et al. 2007, Bradley et al. 2010, Lindehoff et al. 2010). Benthic microalgal species have been found to take up labile DON fractions, such as urea and DFAA (Admiraal et al. 1987, Nilsson \& Sundbäck 1996, Rondell et al. 2000, Tuchman et. al 2006). Because sediments are sites of remineralization, and are also habitats where light is limiting below the very surface of the sediment, the capability to use organic substrates should be an advantage. In addition, DIN can become limiting, particularly in sandy sediments with low organic content (e.g. Nilsson et al. 1991, Lever \& Valiela 2005). Our knowledge of the quantitative role of DON for natural communities of the MPB is, however, still limited (Linares \& Sundbäck 2006, Veuger \& Middelburg 2007).

We aimed to investigate the role of various forms of DIN and DON for meeting the nitrogen requirements of benthic microalgae in a microtidal shallow-water, sandy sediment. The working hypothesis was that various forms of DON will become important for sustaining the generally high productivity of the microphytobenthos when the availability of DIN is low. To test our hypothesis, we measured the uptake rates of ${ }^{15} \mathrm{~N}$ labelled nitrate, ammonium, urea and 2 amino acidsglycine (GLY) and glutamic acid (GLU) - in slurries of natural microbenthic communities in laboratory incubations under simulated in situ light and temperature conditions. The activities of the hydrolytic ectoenzymes leucine aminopeptidase (AMA), alkaline phosphatase (APA), and $\beta$-glucosidase (GLA) were measured in the surface sediment to check for nitrogen, phosphorus and inorganic carbon limitation, respectively, and to estimate the rate of nutrient turnover (Sala et al. 2001). Microphytobenthic primary production and chlorophyll (chl a) were also measured, and species composition was checked by epifluorescence microscopy. Our aim was not to study in situ temporal and spatial variation of nitrogen uptake by the MPB, but to get a first insight into the role of DON in meeting the nitrogen demand of the MPB under assumed Nlimited conditions.

\section{MATERIALS AND METHODS}

Study site and sampling. Sediment was collected at a water depth of ca. $0.3 \mathrm{~m}$ in a sandy bay on the Island of Öland $\left(56^{\circ} 40^{\prime} \mathrm{N}, 16^{\circ} 22^{\prime} \mathrm{E}\right)$, Baltic Sea proper. This area, on the east coast of Sweden in the Kalmar Sound, is virtually non-tidal, with a salinity range of 7 to 9 . This particular site was chosen because a previous field study had shown that fluxes of both DIN and DON into the sediment in spring were high (at the site Öland North, in Sundbäck et al. 2006). The sediment consists of fine sand (90\% grain size 100 to $250 \mu \mathrm{m})$, with a porosity of $\sim 0.5$, the total organic carbon (TOC) content being $\leq 0.2 \%$, and the total organic nitrogen (TON) content $\leq 0.02 \%$. In spring (April) and early autumn (September), the water-column concentrations of DIN were $<1 \mu \mathrm{M}$, while concentrations of DON were 20 to $30 \mu \mathrm{M}$ (Sundbäck et al. 2006).

Sampling was done on June 25, 2007. Sediment was collected in 3 ways: (1) Core samples of undisturbed sediment (ca. $7 \mathrm{~cm}$ deep) for analyses of chl $a$, ectoenzymes and microscopy of the microbenthic community were taken using Plexiglas cores (internal diameter $8 \mathrm{~cm}$, height $10 \mathrm{~cm}$ ), referred to as field cores. Nine such cores were taken. (2) For slurry incubations 
with ${ }^{15} \mathrm{~N}$-labelled $\mathrm{N}$ fractions and parallel ${ }^{14} \mathrm{C}$-uptake measurements, the $\sim 0.5 \mathrm{~cm}$ top layer of sediment was gently scraped off, using a small plastic spade, from 4 randomly distributed squares of $18 \times 18 \mathrm{~cm}$, equalling the area of a plastic box. (3) For analyses of pore water nutrients, 10 sediment cores were collected using 50 $\mathrm{ml}$ cut-off disposable syringes; the top $1 \mathrm{~cm}$ from 5 of the syringe cores were pooled in 1 disposable $50 \mathrm{ml}$ centrifuge tube. Surface water was collected in acidwashed plastic polyethylene $5 \mathrm{l}$ bottles for nutrient analysis and laboratory incubations. At the time of the sampling, salinity was 7.1 and water temperature $18^{\circ} \mathrm{C}$. Light was measured in the field with a QSL-100 spherical quantameter (Biospherical Instruments). The material was transported to the laboratory in cool boxes. In the laboratory, the scraped-off surface sediment was gently sieved (mesh size: $500 \mu \mathrm{m}$ ) to remove macrofauna, and allowed to settle in a plastic box $(18 \times$ $18 \mathrm{~cm}$ ) overnight. All 4 of the $0.5 \mathrm{~cm}$ layers were combined to form a $\sim 2 \mathrm{~cm}$ deep layer (a depth suitable for sampling by syringe corers). The box containing the scraped-off sediment and the intact field cores was placed in a thermo-constant room at $19^{\circ} \mathrm{C}$ under a light level of ca. $650 \mu \mathrm{mol}$ photons $\mathrm{m}^{-2} \mathrm{~s}^{-1}$ (16:8 h light:dark cycle) provided from mercury lamps (Osram Powerstar HQI-E-250W/Day Light).

Nutrient analyses. Nutrient concentrations were measured in both the surface seawater and the pore water. Pore water was extracted by centrifugation (11800 $\times$ g, $20 \mathrm{~min})$. Inorganic nutrients $-\mathrm{NO}_{3}{ }^{-}+\mathrm{NO}_{2}{ }^{-}$ (hereafter referred to as $\mathrm{NO}_{3}{ }^{-}$), $\mathrm{PO}_{4}{ }^{3-}$ and $\mathrm{NH}_{4}{ }^{+}$- and total nitrogen (TN) and phophorus (TP) were analysed (Valderrama 1995). $\mathrm{Si}(\mathrm{OH})_{4}$ was measured only in the overlying water. Urea measurements were based on the reaction of urea with diacetylmonoxime (Goeyens et al. 1998), modified by Mulvenna \& Savidge (1992). Concentrations of total DFAA were analysed by fluorometry (Parsons et al. 1984). Concentrations of individual amino acids were not measured. Concentrations of GLY and GLU in the surface water were estimated to be 20 and $10 \%$, respectively, of the total DFAA pool (Macko \& Green 1982). For the pore water, we assumed a GLY proportion of $9 \%$ and a GLU proportion of $12 \%$ (Guldberg et al. 2002).

Pigments and algal composition. The content of chl a was measured in the top $5 \mathrm{~mm}$ of the undisturbed sediment cores, as this layer includes all photosynthetically active algae (photic zone $\leq 3 \mathrm{~mm}$; Kühl \& Jørgensen 1992). Chl a was also measured in the homogenized sediment incubated in the laboratory. Sediment was collected with a cut-off $5 \mathrm{ml}$ syringe (area $1.11 \mathrm{~cm}^{2}$ ). For extraction, ethanol was used instead of acetone (Jespersen \& Christoffersen 1987), because ethanol easily penetrates even the hardest cell walls of microalgae, including cyanobacteria. The specific absorption coefficient of chl $\mathrm{a}$ in ethanol is 83.4 while it is $87.7 \mathrm{~g}^{-1} \mathrm{~cm}^{-1}$ in acetone (Lorenzen \& Jeffrey 1980). This difference should, however, not constitute a problem because chlorophyll is excited at the same wavelength $(485 \mathrm{~nm})$ and the emission is covered on a band $50 \mathrm{~nm}$ wide $(685 \pm 50 \mathrm{~nm})$. The samples were vortexed repeatedly, and chl a concentrations were corrected for pheopigments by acidification (Lorenzen 1967) and measured in a Turner Designs ${ }^{\mathrm{R}}$ Trilogy laboratory fluorometer, using Turner filters and solid standards.

Fresh sediment samples were scanned in an epifluorescence microscope to get an overall view of the composition of the MPB. Later, the relative abundance of algal cells in freezer-stored samples from 3 of the in situ sediment cores was assessed in an epifluorescence microscope at 500 $\times$ magnification (Sundbäck et al. 2010).

Ectoenzyme activity. Ectoenzyme activity was measured in the field cores on the day of collection. Activities of the 3 hydrolytic ectoenzymes (APA, AMA and GLA) were measured in the top $0.5 \mathrm{~cm}$ of sediment. Five samples were taken with a cut-off $5 \mathrm{ml}$ disposable syringe (i.d. $1.11 \mathrm{~cm}^{2}$ ) from each of 6 field cores. Five such samples were placed in each of 5 small beakers, with $50 \mathrm{ml}$ of filtered surface water. Enzyme activities were measured before and after ultrasonication (Misonix $^{\circledR}$ XL-2020 Sonicator, 600 W, 20 kHz, 419 standard microtip, sequences of $10 \mathrm{~s}$ burst/2 to $3 \mathrm{~s}$ pause during 4 min at amplitude 2.5), while cooling with ice. The efficiency of the ultrasonication was checked in the epifluorescence miroscope to verify that most of the phototrophic cells had been detached from the sediment particles, assuming that bacteria had also been detached. To separate bacterial from phototrophic activity, ultrasonicated samples were size-fractionated by filtering through Nuclepore polycarbonate filters of $1 \mu \mathrm{m}$ pore size. The fluorogenic substrates 4 methylumbelliferyl phosphate, L-leucine 7-amino-4methyl coumarin and 4-methylumbelliferyl- $N$-acetyl $\beta$-glucosidase (Sigma) were used in the enzyme assays (Pettersson \& Jansson 1978, Hoppe 1993), applying modifications according to Martinez et al. (1996). The final concentration of each substrate was $50 \mu \mathrm{M}$, which was added to 2 different sets of $4 \mathrm{ml}$ sample aliquots. Filtered (Whatman GF/F) and autoclaved water from the sampling site was used for blanks. Samples and blanks were incubated for 10 to $60 \mathrm{~min}$ at room temperature. The increase in fluorescence during the incubation was measured with a Turner TD-700 fluorometer, which had been calibrated with standards of 4-methylumbelliferyl phosphate (for APA and GLA) and 7-amino-4-methyl-coumarin (for AMA). Results (nmol cm $\mathrm{cm}^{-3}$ wet sediment $\mathrm{h}^{-1}$ of $\mathrm{P}, \mathrm{N}$ and $\mathrm{C}$ ) were converted to $\mathrm{mmol} \mathrm{m} \mathrm{m}^{-2} \mathrm{~h}^{-1}$, to enable comparisons with other measured rates. 
Uptake of nitrogen fractions. Slurries of natural sandy sediments were incubated in the laboratory with the addition of ${ }^{15} \mathrm{~N}$-labelled substrates on the day after the field collection. From the sieved sediment in the box, cores from the top $1 \mathrm{~cm}$ of sediment were taken using a cut-off $2 \mathrm{ml}$ disposable syringe (area $0.754 \mathrm{~cm}^{2}$ ). One such sample was transferred to each of 55 Falcon tubes $(15 \mathrm{ml})$, and each tube was filled to a final volume of $10 \mathrm{ml}$ of filtered seawater (FSW) (1.2 $\mu \mathrm{m}$, Munktell glass-fibre filter) from the sampling site. The samples were enriched with various ${ }^{15} \mathrm{~N}$ substrates to 5 final concentrations ranging from 0.5 to $20 \mu \mathrm{M}: \mathrm{NO}_{3}$, urea and $\mathrm{NH}_{4}$ (final concs. 0.5, 1, 2, 5 and $10 \mu \mathrm{M}$ ), GLU and GLY (final concs. 1, 2, 5, 10 and $20 \mu \mathrm{M}$ ), all enriched in ${ }^{15} \mathrm{~N}$ to between 97 and $99 \%$ (Cambridge Isotope Laboratories). GLU and GLY were chosen because they are among the dominating DFAA in coastal waters and sediments (Tyler et al. 2003). DFAA have been found to constitute 10 to $31 \%$ of DON in the upper centimetre of shallow-water sediments (Guldberg et al. 2002). One tube for each substrate and concentration was used (25 tubes). As organic substrates can be bound to sediment particles (Aufdenkampe et al. 2001), heat-killed samples (30 min at $60^{\circ} \mathrm{C}$ ) were used as controls for adsorbed ${ }^{15} \mathrm{~N}$. To discriminate between eukaryotic and prokaryotic uptake, the bacteriostatic inhibitor chloramphenicol (CAP) (20 $\mu_{\mathrm{mol}}{ }^{-1}$ final conc.; Linares \& Sundbäck 2006) was added 30 min prior to incubation. The 2 control series (heat and CAP) were incubated under conditions identical to those used for the regular samples at the lowest, middle and highest substrate concentrations $(15+15$ tubes). Incubations were at $19^{\circ} \mathrm{C}$ at light intensities that varied between 618 and $754 \mu \mathrm{mol}$ photons s $\mathrm{sm}^{-1}$ (16:8 h light:dark cycle), simulating in situ conditions. The tubes were positioned horizontally on a table, letting the sediment spread evenly out in the tube. During the incubation, the tubes were gently shaken and moved around randomly to ensure even light exposure for all tubes. After $1 \mathrm{~h}$, the incubations were stopped and the samples centrifuged $(2550 \times g, 3 \mathrm{~min})$. The supernatant was discarded to remove the remaining ${ }^{15} \mathrm{~N}$ substrate. Samples were washed twice with $10 \mathrm{ml}$ FSW before the sediment pellet was transferred, using a small volume of FSW and a cut-off pipette tip, to precombusted $\left(450^{\circ} \mathrm{C}, 2 \mathrm{~h}\right)$ scintillation vials and immediately frozen $\left(-80^{\circ} \mathrm{C}\right)$ for storage until packing. The samples were freeze-dried and the residual was packed in tin cups $(5 \times 8 \mathrm{~mm})$. Sediment material (ca. $115 \mathrm{mg}$ ) corresponding to $\sim 1.5 \mu \mathrm{g} \mathrm{chl}$ a per sample (to ensure enough element for detection) was weighed and packed. The samples were analysed in an isotope ratio mass spectrometer (PDZ Europa ANCA IRMS) at the University of Maryland Center for Environmental Science, USA.
The primary data for uptake rates of ${ }^{15} \mathrm{~N}$-labelled nitrogen were expressed as nitrogen-specific uptake rates $\left(V \mathrm{~h}^{-1}\right)$ interpreted as $\mathrm{N}$ taken up per cell $\mathrm{N}$ over time (Glibert et al. 2006), based on Eq. (1) in Dugdale \& Goering (1967):

$$
\begin{gathered}
V=(\text { atom } \% \text { excess }) /(\text { atom } \% \text { enrichment } \times \\
\text { incubation time })
\end{gathered}
$$

where atom \% excess is the excess ${ }^{15} \mathrm{~N}$ incorporated into the cells compared to the standard (natural abundance), and atom \% enrichment is the percentage added ${ }^{15} \mathrm{~N}$ of the total ambient $\mathrm{N}$ substrate. Because the original sample volume and corresponding sediment surface were known $\left(0.754 \mathrm{~cm}^{3}\right.$ and $0.754 \mathrm{~cm}^{2}$, respectively), $\mathrm{V}$ could be converted to areal uptake $\left(\mu \mathrm{mol} \mathrm{N} \mathrm{m} \mathrm{N}^{-2} \mathrm{~h}^{-1}\right.$ ) of $\mathrm{N}$. When saturated uptake was reached within the range of substrate concentrations used, parameters of $\mathrm{N}$ uptake kinetics were calculated using the Michaelis-Menten equation:

$$
V=\left(V_{\max } \times S\right) /\left(K_{\mathrm{S}}+S\right),
$$

where $V$ is the specific uptake rate $\left(\mathrm{h}^{-1}\right), V_{\max }$ is the maximum specific uptake rate, $S$ is the substrate concentration $(\mu \mathrm{M}-\mathrm{N})$ and $K_{\mathrm{S}}$ is the half-saturation constant, i.e. the concentration at which $V$ is equivalent to half of $V_{\max }$. Where no evidence of saturation was apparent, a linear model was used. The data were fitted to a hyperbolic or linear equation using Jandel Scientific Sigmaplot 10.0 for Windows. Using the parameters derived from these equations for each substrate, uptake rates at pore water or seawater concentrations were calculated.

In sediments, only a fraction of the particulate nitrogen $(\mathrm{PN})$ originates from live organisms (e.g. Sundbäck et al. 1996) and it is therefore not possible to use $\mathrm{PN}$ for the calculation of absolute $\mathrm{N}$ uptake rate per volume. However, from the chl a content of the ${ }^{15} \mathrm{~N}$ labelled sediment $\left(6.9 \mathrm{mg}\right.$ chl a sample $\left.{ }^{-1}\right)$, it was possible to estimate the proportion of algal uptake by using an assumed mean C:chl a weight ratio and $\mathrm{C} / \mathrm{N}$ molar ratio of the algal community. We used the traditional Redfield ratio of 6.6 because it agrees with the mean ratio found in a $\mathrm{C}$ and $\mathrm{N}$ incorporation experiment in subtidal sand (Evrard et al. 2008). Because the C:chl a ratio of the MPB varies greatly, we applied mean ratios of both 30 and 50 (de Jonge 1980, Sundbäck \& Miles 2000).

Relative preference index (RPI). Uptake of a particular nitrogen fraction, relative to its availability, was calculated using the RPI (McCarthy et al. 1977). For example, the equation used to calculate the preference for $\mathrm{NO}_{3}{ }^{-}$is:

$$
\begin{gathered}
\mathrm{RPI}_{\mathrm{NO}_{3}}=\left[\left(V_{\mathrm{NO}_{3}}\right) /\left(V_{\mathrm{NO}_{3}}+V_{\mathrm{NH}_{4}}+V_{\mathrm{urea}}+V_{\mathrm{GLU}}+V_{\mathrm{GLY}}\right)\right] / \\
{\left[\mathrm{NO}_{3}^{-} /\left(\mathrm{NO}_{3}^{-}+\mathrm{NO}_{4}^{+}+\text {urea }+\mathrm{GLU}+\mathrm{GLY}\right)\right]}
\end{gathered}
$$


where $V_{\mathrm{NO}_{3}}, V_{\mathrm{NH}_{4}}, V_{\text {urear }}, V_{\mathrm{GLU}}$ and $V_{\mathrm{GLY}}$ are the $\mathrm{N}$ specific uptake rates of each tested substrate, and $\mathrm{NO}_{3}{ }^{-}, \mathrm{NH}_{4}{ }^{+}$urea, GLU and GLY are the substrate concentrations found in sediment pore water. The RPI was calculated for the ambient pore water concentrations, assuming that, in situ, the sediment would be the main source of nutrients for the MPB. An RPI value $>1$ indicates a preference for that substrate relative to its availability, while an RPI $<1$ indicates discrimination.

Primary production and estimation of $\mathbf{N}$-demand. Sediment for measuring primary production of the MPB was collected from the same box as that used for ${ }^{15} \mathrm{~N}$ uptake measurements, and was measured by the ${ }^{14} \mathrm{C}$ technique in sediment slurries. A slurry, rather than intact sediment, was incubated to enable a rough calculation of the $\mathrm{N}$-demand of the microbenthic community under the same conditions as those experienced by the organisms during the ${ }^{15} \mathrm{~N}$ incubations. Using a 2 $\mathrm{ml}$ cut-off syringe (area $0.754 \mathrm{~cm}^{2}$ ), 5 sediment plugs were taken (3 replicates for light incubations and 2 for dark controls) to correct for non-photosynthetic carbon uptake. The sediment was incubated with $6 \mathrm{ml}$ of FSW and $2 \mu \mathrm{Ci}$ of ${ }^{14} \mathrm{C}$-sodium bicarbonate (Amersham CFA.3) at the same time and under the same conditions as the ${ }^{15} \mathrm{~N}$-uptake incubations. During the $1 \mathrm{~h}$ incubation, the tubes were moved around and gently shaken once. After incubation, the samples were treated as described in Sundbäck et al. (1989) and counted in a Wallac Winspectral 1414 liquid scintillation counter. Primary production was calculated according to the formulae of Aertebjerg Nielsen \& Bresta (1984) modified for sediment. Primary production rates were used to estimate the theoretical nitrogen demand of the MPB assuming a fixed C:N molar ratio of 6.6 (see 'Uptake of nitrogen fractions'). For comparison with previously measured sediment-water $\mathrm{N}$ fluxes in undisturbed sediment cores, the slurry rates for a deep plug of $1 \mathrm{~cm}$ were corrected to apply to the $0.5 \mathrm{~cm}$ of intact sediment by dividing the rate by 2 and multiplying by a factor of 0.22 (Jönsson 1991).

Statistics. For each substrate, a 1-way ANOVA was used to compare uptake rates at different concentrations. Homogeneity of variances was tested using Cochran's test, and heterogeneous data were transformed according to Underwood (1997).

\section{RESULTS}

\section{Sediment properties and the microphytobenthic community}

Sediment characteristics were not measured at the actual time of sampling, but were measured in a previous study at the same site (Sundbäck et al. 2006). The concentration of chl a (proxy for the MPB biomass) in the top $0.5 \mathrm{~cm}$ sediment of the undisturbed field cores was $54 \mathrm{mg} \mathrm{m}^{-2}(\mathrm{SE} \pm 4.6, \mathrm{n}=5)$ (compared to $43 \mathrm{mg} \mathrm{m}^{-2}$ in the box). Epifluorescence microscopy of fresh sediment showed that the majority of algal cells were attached to sediment particles, i.e. the microphytobenthic community was mainly epipsammic. Later cell counts (relative abundance converted to biomass) suggested that, on average, $67 \%$ of the biomass consisted of pennate diatoms (small Fragilaria, naviculoids), $28 \%$ of cyanobacteria (Anabaena, Microcrocis and pico-sized Synechococcus-like cells attached to sediment particles), with the rest (5\%) being small flagellates (e.g. cryptophytes).

The primary production of the sediment was $214 \mathrm{mg}$ $\mathrm{C} \mathrm{m}^{-2} \mathrm{~h}^{-1}( \pm 28.6 \mathrm{SE})$, representing a sediment layer of $1 \mathrm{~cm}$. Primary production in the topmost $0.5 \mathrm{~cm}$ of undisturbed sediment was therefore estimated to be 24 $( \pm 6.3) \mathrm{mg} \mathrm{C} \mathrm{m}^{-2} \mathrm{~h}^{-1}$ (i.e. $214 / 2 \times 0.22$; see 'Materials and methods').

\section{Enzyme activity}

Ectoenzyme activities suggested that the microbenthic community was nitrogen limited. The fact that enzyme activity in the total ultrasonicated samples ( $>1 \mu \mathrm{m}+<1 \mu \mathrm{m}$ fractions) was several times higher than in the unsonicated samples (5 times higher for AMA and APA, 7 times higher for GLA) suggests that the enzymic activity was related mainly to organisms attached to sand grains (Fig. 1). Therefore, only sonicated samples will be considered further. Average rates for the $>1 \mu \mathrm{m}$ fraction, which we assumed to be dominated by algal cells, were $5.4 \pm 1.1$ for AMA, 0.4 \pm 0.3 for APA and $0.7 \mathrm{mmol} \mathrm{m} \mathrm{m}^{-2} \mathrm{~h}^{-1}$ for GLA. The high AMA and the low APA and GLA rates show that the algal populations were severely N-deficient, possessing a capacity to assimilate much more nitrogen (and produce biomass) than was available at the time of the sampling. On the other hand, as well as being $\mathrm{N}$-deficient (high AMA of $5 \pm 2.7 \mathrm{mmol} \mathrm{N} \mathrm{m}^{-2} \mathrm{~h}^{-1}$ ), bacteria were also deficient in phosphorus (APA of $3 \pm 1.7 \mathrm{mmol} \mathrm{P} \mathrm{m} \mathrm{m}^{-2} \mathrm{~h}^{-1}$ ) (Fig. 1). Almost $90 \%$ of the APA activity originated from the bacterial $(<1 \mu \mathrm{m})$ fraction, compared to only $15 \%$ of the GLA activity.

\section{Nitrogen uptake}

\section{Kinetics}

Over the concentration ranges used, only nitrate uptake reached saturation, fitting a hyperbolic relationship $\left(K_{\mathrm{S}}=3.4 \mu \mathrm{M}, V_{\max }\right.$ 0.0029) (Fig. 2). The other 
substrates fit best to a linear model (Fig. 2) and therefore $V_{\max }$ or $K_{\mathrm{S}}$ could not be determined. The highest $V$ rates for all $\mathrm{N}$ fractions were within the same magnitude (0.002 to $0.005 \mathrm{~h}^{-1}$ ) (Fig. 2). Assuming that the

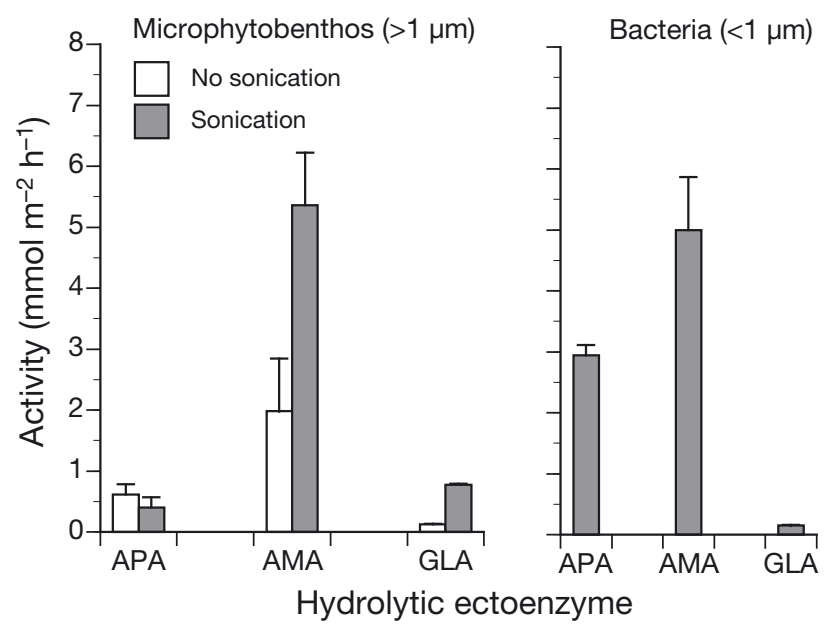

Fig. 1. Activity of the 3 hydrolytic ectoenzymes alkaline phosphatase (APA), leucine aminopeptidase (AMA) and $\beta$-glucosidase (GLA) in the top $0.5 \mathrm{~cm}$ sediment sampled from intact sediment in situ. Activities are shown for subsamples before and after ultrasonication and for 2 size fractions of sonicated samples $(>1 \mu \mathrm{m}$ and $<1 \mu \mathrm{m})$. Mean values are shown $\pm \mathrm{SE}$ $(\mathrm{n}=3)$ organisms in situ are exposed mainly to pore water concentrations, applied concentrations either did not saturate uptake potential, or the uptake did not follow Michaelis-Menten kinetics, but rather a linear model. Because rates for the MPB are generally expressed per area, we also present ${ }^{15} \mathrm{~N}$-uptake rates per $\mathrm{m}^{2}$ (Fig. 2). Maximum areal uptake rates for all substrates were within the range 150 to $300 \mu \mathrm{mol} \mathrm{m}^{-2} \mathrm{~h}^{-1}$. These rates should, however, be considered as potential rates because they were measured in a slurry in which the algae are exposed to more light than in an intact sediment with a sharp gradient of light in the upper $\sim 3 \mathrm{~mm}$ (cf. Jönsson 1991).

\section{Estimated proportion of 'algal' uptake}

The addition of CAP clearly affected only the uptake of urea, although eukaryotic uptake still represented $\sim 70 \%$ of the total uptake. For other $\mathrm{N}$ fractions, CAP lowered the uptake only marginally or not at all (Fig. 2). $\mathrm{NO}_{3}{ }^{-}$appeared to be taken up only by eukaryotic primary producers. For $\mathrm{NH}_{4}{ }^{+}$, a prokaryotic uptake was indicated ( $15 \%$ of total uptake) only for the highest concentration $(10 \mu \mathrm{M})$, which also applied to GLU $(\sim 20 \%)$ and GLY $(\sim 15 \%)$. The curves suggest that eukaryotic phototrophs accounted for 70 to $100 \%$ of
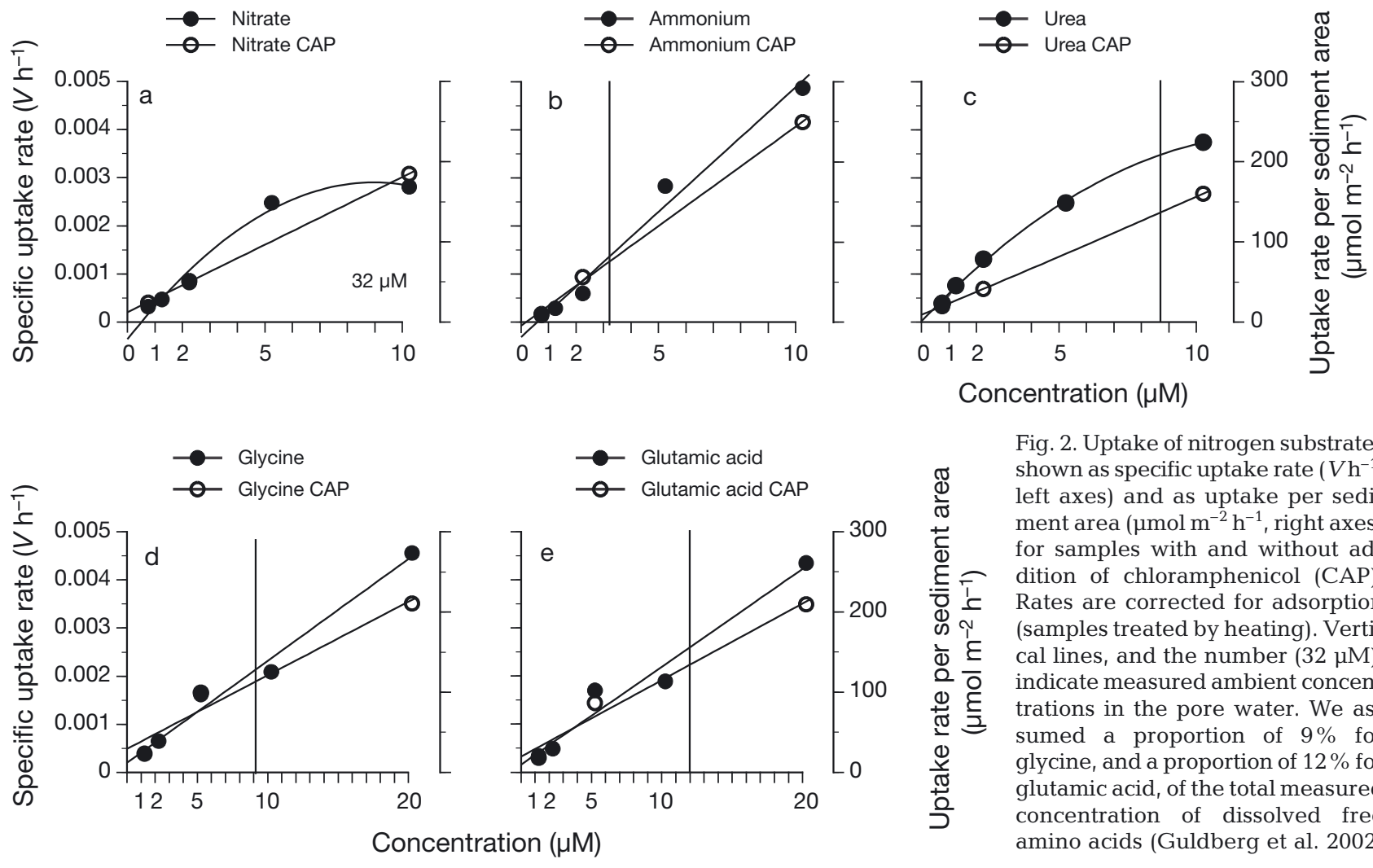

Fig. 2. Uptake of nitrogen substrates shown as specific uptake rate $\left(V \mathrm{~h}^{-1}\right.$, left axes) and as uptake per sediment area ( $\mu \mathrm{mol} \mathrm{m}{ }^{-2} \mathrm{~h}^{-1}$, right axes) for samples with and without addition of chloramphenicol (CAP). Rates are corrected for adsorption (samples treated by heating). Vertical lines, and the number $(32 \mu \mathrm{M})$, indicate measured ambient concentrations in the pore water. We assumed a proportion of $9 \%$ for glycine, and a proportion of $12 \%$ for glutamic acid, of the total measured concentration of dissolved free amino acids (Guldberg et al. 2002) 
the ${ }^{15} \mathrm{~N}$ uptake. However, because of few measuring points, these numbers have to be interpreted with caution.

An alternative method for estimating the proportion of nitrogen uptake by primary producers, including prokaryotes (cyanobacteria), is basing the estimate on the content of chl $a$, assuming certain $C: c h l$ and $C: N$ ratios (see 'Materials and methods'). These calculations rendered mean values of $54 \%$ (C:chl a 30) and $89 \%$ (C:chl a 50) of total uptake of nitrogen. These percentages agree reasonably well with the CAP-induced decrease in uptake rates, although they are somewhat lower. There were no statistically significant differences between the substrates regarding the estimated proportion of 'algal' uptake.

\section{Proportional uptake of DIN and DON fractions}

At all concentrations used, the uptake of DON (i.e. urea + GLY + GLU) accounted for more than half (51 to $68 \%$, mean $61 \%$ ) of the total uptake of added ${ }^{15} \mathrm{~N}$-substrates (Fig. 3). At low additions (1 and $2 \mu \mathrm{M})$, the proportion of DON uptake (mean $65 \%$ ) was significantly higher than at the higher additions of 5 and $10 \mu \mathrm{M}$ (mean $52 \%$ ) (ANOVA, $\mathrm{p}=0.013, \mathrm{n}=2$ ). This difference was due to a higher uptake of urea and GLY relative to added substrate concentration, while the proportional uptake of GLU did not depend on the concentration. Urea was the DON fraction that showed the highest uptake rate, with significantly higher proportional uptake at the lower $\mathrm{N}$ additions (33\%) than at higher $\mathrm{N}$ additions $(23 \%)$ (ANOVA, $p=0.017$ ). The 2 amino acids accounted for 13 to $17 \%$ each of the total uptake of nitrogen. GLY uptake was significantly higher (ANOVA, $\mathrm{p}=0.034$ ) at the 2 lower concentrations $(\leq 2 \mu \mathrm{M})$, but this difference did not apply to GLU. Also, $\mathrm{NH}_{4}{ }^{+}$uptake was higher at higher concentrations $(\geq 5 \mu \mathrm{M}$ ) (ANOVA, $\mathrm{p}=0.019$ ). Based on the kinetic relationships, DON uptake by the microbenthic community at pore water concentrations was estimated to be $65 \%$ of the total uptake of nitrogen.

Assuming that the MPB we studied under N-limiting conditions rely mainly on pore water as a source of nitrogen, the calculated RPI suggests that none of the 5 substrates tested were discriminated against (Fig. 4). The order of RPI was $\mathrm{NH}_{4}>$ urea $>$ GLU $>\mathrm{NO}_{3}>\mathrm{GLY}$.

\section{Estimated N demand of the MPB}

Although measurements of primary production were made in slurries, these rates can be used to provide a rough estimate of the theoretical $\mathrm{N}$-demand of the MPB (e.g. Sundbäck et al. 2006), assuming a C:N ratio of 6.6. The mean primary production measured in the slurry was $214 \mathrm{mg} \mathrm{C} \mathrm{m}^{-2} \mathrm{~h}^{-1}\left(17.8 \mathrm{mmol} \mathrm{C} \mathrm{m}^{-2}\right.$ $\mathrm{h}^{-1}$ ), which corresponds to an $\mathrm{N}$-demand of $2.7 \mathrm{mmol}$ $\mathrm{N} \mathrm{m}^{-2} \mathrm{~h}^{-1}$. For the measured pore water concentrations, the sum of the uptake of the $\mathrm{N}$ fractions was $\sim 700 \mu \mathrm{mol} \mathrm{m} \mathrm{m}^{-2} \mathrm{~h}^{-1}$ (Fig. 2), which is only $26 \%$ of the estimated demand $\mathrm{h}^{-1}$ in light. This result implies that the MPB was extremely N-deficient, as was also suggested by the AMA activity, corresponding to a capacity for nitrogen turnover of up to $7 \mathrm{mmol} \mathrm{N} \mathrm{m}^{-2}$ $\mathrm{h}^{1}$. This is an order of magnitude higher than the one suggested by the kinetics. Considering that uptake of remineralized nitrogen by the MPB in the sediment can also occur during the night (Anderson et al. 2003,

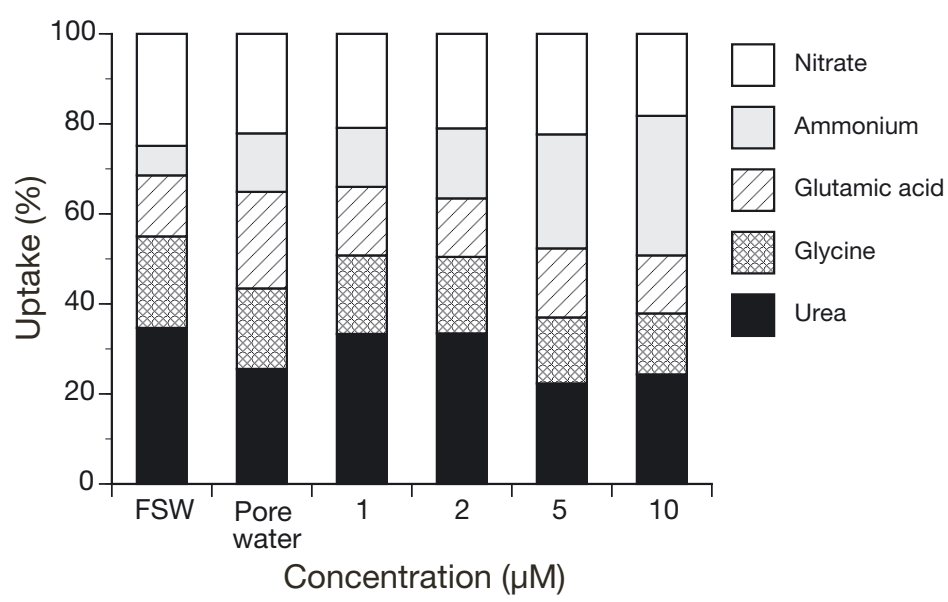

Fig. 3. Proportional uptake of nitrogen fractions at different substrate concentrations, and for ambient concentrations in filtered seawater (FSW) and sediment pore water

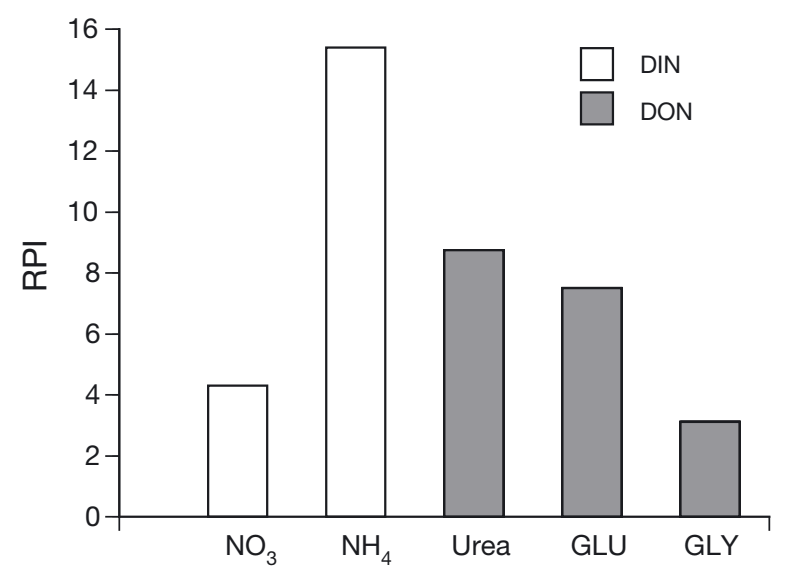

Fig. 4. Relative preference index (RPI) for dissolved inorganic nitrogen (DIN) and dissolved organic nitrogen (DON) fractions calculated for ambient pore water concentrations. We assumed a proportion of $9 \%$ for glycine (GLY), and a proportion of $12 \%$ for glutamic acid (GLU), of the total measured concentration of dissolved free amino acids (Guldberg et al. 2002) 
Evrard et al. 2008), 26\% may be an underestimated proportion. Previous light/dark measurements of sediment-water $\mathrm{N}$ fluxes, however, suggest that the uptake is generally lower in the dark, often turning uptake during daylight into an efflux during the night (e.g. Sundbäck et al. 2006, Cook et al. 2007 and references therein). If we assume that uptake of nitrogen in the dark is $50 \%$ of that in light, then the measured uptake would supply up to ca. $50 \%$ of the sediment $\mathrm{N}$-demand on a daily (24 h) scale.

\section{DISCUSSION}

Our results support the hypothesis that, during low availability of DIN, organic nitrogen can indeed be an important source of nitrogen for the MPB-particularly in sandy, organically poor sediments. The total uptake of DON (i.e. urea + GLU + GLY) accounted for $\sim 50$ to $65 \%$ of the uptake of ${ }^{15} \mathrm{~N}$-labelled substrates, and a significantly higher proportion of DON uptake was observed at low concentrations of added substrates $(\leq 2 \mu \mathrm{M})$, further supporting our conclusion. Measured total uptake rates at pore water $\mathrm{N}$ concentrations were estimated to meet only one-quarter of the theoretical hourly demand for nitrogen by the MPB, and one-half of the daily demand (assuming uptake also in the dark), suggesting that ambient pore water concentrations were not sufficient for the algal $\mathrm{N}$ demand. High activity of AMA also showed that nitrogen limited the microbenthic community (both primary producers and bacteria) at the time of the experiment. The 'bacterial' fraction appeared to be also limited by phosphorus.

\section{Nutrient limitation}

Nitrogen limitation of the microbenthic community was suggested by the high activity of AMA, nonsaturated nitrogen kinetics (except for nitrate), and the fact that the estimated N-demand of the MPB $(2.7$ mmol $\mathrm{N} \mathrm{m}^{-2} \mathrm{~h}^{-1}$ ) exceeded the calculated $\mathrm{N}$ uptake $\left(\sim 0.7 \mathrm{mmol} \mathrm{m}^{-2} \mathrm{~h}^{-1}\right)$ by a factor of 4 . Concentrations of DIN in the pore water were within the range of those previously found for similar sandy sediments (Sundbäck et al. 2003, Engelsen et al. 2008), and AMA was within the range found for shallow-water sandy sediments in an oligotrophic part of the Mediterranean (Misic \& Harriague 2007). While levels of APA were low for the ultrasonicated 'algal' fraction $(>1 \mu \mathrm{m})$, higher APA for the 'bacterial' fraction $(<1 \mu \mathrm{m})$ indicated a limitation of phosphorus. This is not surprising because, for bacteria, the mean intracellular N:P ratio has been found to be 8.5 (Chrzanowski et al. 1996), but is about 16:1 (Redfield ratio) for microalgae growing under NP-sufficient conditions (e.g. Granéli et al. 1990). However, the observed pico-sized Synechococcus-like cyanobacteria could have also contributed to APA in the $<1 \mu \mathrm{m}$ fraction.

\section{Kinetics and preference for $\mathbf{N}$ forms}

Linear kinetics were observed with the exception of $\mathrm{NO}_{3}{ }^{-}$and, to some extent, urea, which showed a tendency to approach saturated uptake at $10 \mu \mathrm{M}$. Linear kinetics have also been observed for the uptake of various $\mathrm{N}$ fractions by plankton (Glibert et al. 2006, Lindehoff et al. 2010), and could be explained by diffusion, as well as by mediated transport (Glibert et al. 2006). Our additions of nitrogen (0.5 to $20 \mu \mathrm{M})$ should have been within the range of realistic concentrations for surface sediments, giving a good indication of nitrogen kinetics in the pore water. As a comparison, Guldberg et al. (2002) found a bulk DON pore water concentration of 113 to $664 \mu \mathrm{M}$, of which DFAA accounted for 10 to $25 \%$, with the concentration of GLU being $15 \mu \mathrm{M}$ and GLY $\sim 4 \mu \mathrm{M}$. Our measured pore water $\mathrm{NO}_{3}$ concentration $(32 \mu \mathrm{M})$ was, however, well above our highest added concentration $(10 \mu \mathrm{M})$. It could be that the saturation we observed for $\mathrm{NO}_{3}$ was in fact the first plateau of 2 uptake mechanisms representing 2 physiological states (Harrison et al. 1976). On the other hand, considering that the sediment system at the time of sampling was strongly $\mathrm{N}$ limited, surface pore water $\mathrm{N}$ concentrations can be expected to be generally low, with the MPB efficiently taking up all remineralized $N$, in agreement with the idea that recycling of nutrients is efficient in the microbial film of the surface sediment (e.g. Lomstein et al. 1998, Veuger et al. 2007). Under such conditions, the sediment community also uses nutrients from the overlying water, as shown by the previous field study in the same area (Sundbäck et al. 2006) and elsewhere (e.g. Billerbeck et al. 2007, Engelsen et al. 2008).

The 2 amino acids accounted for about one-third of the total measured uptake of nitrogen, and GLY uptake was significantly higher (by $20 \%$ ) at concentrations $\leq 2 \mu \mathrm{M}$ than at $\geq 5 \mu \mathrm{M}$. DFAA have been observed to be important sources of nitrogen for both phytoplankton (e.g. Bradley et al. 2010 and references therein; Lindehoff et al. 2010) and the MPB (Linares \& Sundbäck 2006, Veuger et al. 2007). We do not know, however, whether the 2 tested amino acids were actually transported into the cell, or whether they were taken up as ammonium after extracellular amino acid oxidation at the cell surface (Palenik \& Morel 1990, Mulholland et al. 2002, Veuger \& Middelburg 2007). 


\section{Share of algal uptake}

Under N-limiting conditions, the competition between algae and bacteria for nitrogen in surface sediments can be expected to increase (e.g. Cook et al. 2007). Generally, it has been difficult to separate bacterial and algal uptake of nitrogen fractions, and different approaches have been used (for a review see Bronk et al. 2007), including fraction filtration (e.g. Kirchman \& Wheeler 1998), inhibitors of prokaryotic uptake (e.g. Middelburg \& Niewenhuize 2000), flow cytometric sorting (Bradley et al. 2010), and the bacterial biomarker D-alanine (Veuger \& Middelburg 2007). We used 2 of these approaches-filtration and a prokaryotic inhibitor-but we base our conclusion on the substantial uptake of nitrogen by the MPB on multiple lines of direct and indirect observation:

(1) We worked with sandy sediment with a low organic content (TOC $<0.2 \%$ ). Previous studies of similar sediments suggested that, in the photic zone of the sediment (ca. 3 mm; Kühl \& Jørgensen 1992), microalgal biomass and production dominate over bacterial biomass and production in summer (Nilsson et al. 1991, Sundbäck et al. 1996). Moreover, previous measurements in spring on the same sampling site showed that estimated assimilation of nitrogen by the MPB exceeded bacterial denitrification by 1 to 2 orders of magnitude (Sundbäck et al. 2006). During N-limiting conditions, the MPB generally seem to outcompete bacteria involved in N-turnover processes (RisgaardPetersen 2003 and references therein). Hence, it is reasonable to expect that the uptake of nitrogen would be dominated by the MPB, which has also been found for muddy tidal sediments (Veuger \& Middelburg 2007).

(2) The CAP treatment suggested that most of the uptake of nitrogen (70 to $100 \%$ ) was due to eukaryotic organisms. Nitrate appeared not to be taken up at all by bacteria (cf. Bradley et al. 2010), which might be unexpected, as denitrifiers in sediments compete for nitrate (Risgaard-Petersen 2003). But again, denitrification rates measured earlier at the same site were extremely low $\left(<2 \mu \mathrm{mol} \mathrm{m}{ }^{-2} \mathrm{~h}^{-1}\right.$; Sundbäck et al. 2006) and probably occurred below the top $0.5 \mathrm{~cm}$ that we used. There could also be the risk of incomplete inhibition by CAP, as it was added only 30 min before incubation. However, the method was tested in previous experiments on uptake of amino acids in sediment communities; these studies showed that CAP efficiently blocks prokaryotic uptake, which, in this case, was ca. 50 to $80 \%$ of the total uptake (Linares \& Sundbäck 2006). Veuger et al. (2007), who used biomarkers and ${ }^{15} \mathrm{~N}$ to discriminate between algal and prokaryotic uptake of nitrogen $\left(\mathrm{NH}_{4}, \mathrm{NO}_{3}\right.$, urea and an amino acid mixture) on a subtropical mudbank, found that prokaryotes (bacteria+cyanobacteria) took up 50 to $100 \%$ of the nitrogen. Our lower values could be explained by the type of sediment, the general nutrient status, the thin sediment layer used, and the time of the year, which is generally characterized by low mineralization rates. Cook et al. (2007) found that, in a sandy near-shore sediment, bacteria initially incorporated $\sim 20$ to $30 \%$ of ${ }^{15} \mathrm{~N}$, a range that agrees well with the results of our short incubations. Interestingly, Veuger \& Middelburg (2007) found that even on a nutrient-rich heterotrophic mudflat, algae dominated the uptake of amino acids and urea in the surface layer in a $24 \mathrm{~h}$ incubation.

(3) Theoretical calculations based on assumed $\mathrm{C}$ :chl $a$ and $\mathrm{C}: \mathrm{N}$ ratios suggested that the algal uptake of nitrogen corresponded to between 54 and $89 \%$ of the total uptake when applying the $\mathrm{C}$ : $\mathrm{chl}$ a ratios of 30 and 50, respectively. However, in contrast to the CAP control, these calculations did not suggest any clear algal preference for a certain $\mathrm{N}$ fraction; for the total microbenthic community, $\mathrm{NH}_{4}^{+}$had the highest RPI, algal uptake being within the range 47 to $77 \%$. These percentages should, of course, be looked upon as rough estimates because both the $\mathrm{C}: \mathrm{N}$ and $\mathrm{C}: \mathrm{chl}$ a ratios can be expected to vary greatly, but should still give a fair estimate of the range of algal uptake of nitrogen.

(4) The measurements of AMA activity appear at first glance to contradict the conclusion that the algal fraction dominates nitrogen uptake because the rates were similar for the $<1 \mu \mathrm{m}$ and the $>1 \mu \mathrm{m}$ fractions. Although the $<1 \mu \mathrm{m}$ fraction could be assumed to consist mainly of heterotrophic bacteria, the observed pico-sized Synechococcus-like cyanobacteria may have contributed to the 'bacterial' AMA results. Planktonic Synechococcus do take up amino acids (Paerl 1991, Wawrik et al. 2009) and are also found in benthic microbial mats (Ramsing et al. 2000). Moreover, a previous microautoradiography study showed that colonial cyanobacteria in sandy sediment utilized a mixture of dissolved amino acids (Nilsson \& Sundbäck 1996). Interestingly, the highest activity of GLA, which is considered to reflect mainly bacterial activity (e.g. Misic \& Harriague 2007), was found in the sonicated $>1 \mu \mathrm{m}$ 'algal' fraction, suggesting that algae may have been mainly responsible for GLA, although this fraction may also have included some bacteria.

\section{Nitrogen demand of the MPB and sediment-water fluxes}

Although our study was based on slurry incubations, it may still be interesting to compare measured uptake rates with the $\mathrm{N}$-demand and flux rates with in situ conditions. To be able to do this, we must base our cal- 
culation of the potential N-demand of the MPB on primary production corrected to apply to $0.5 \mathrm{~cm}$ of undisturbed sediment (24 mg C m${ }^{-2} \mathrm{~h}^{-1}$; see 'Materials and methods' and 'Results'). This calculation results in a microphytobenthic N-demand of roughly $300 \mu \mathrm{mol} \mathrm{m}{ }^{-2}$ $\mathrm{h}^{-1}$ (C:N 6.6). In the present study we did not measure primary production or sediment-water exchange of DIN or DON in situ, but we have earlier data from the same site (Sundbäck et al. 2006). In April, net primary production (NPP), measured as oxygen flux in intact sediment, was $19 \mathrm{mg} \mathrm{C} \mathrm{m}^{-2} \mathrm{~h}^{-1}$ (a photosynthetic quotient [PQ] of 1.2 was assumed). Gross primary production (GPP) was only slightly higher $\left(20 \mathrm{mg} \mathrm{C} \mathrm{m}^{-2} \mathrm{~h}^{-1}\right)$ than NPP because of low community respiration. These production rates are close to the calculated value ( $24 \mathrm{mg} \mathrm{C} \mathrm{m}^{-2} \mathrm{~h}^{-1}$ ) for intact sediment in the present study. In spring, the mean influx of nitrogen in light at the same site (Sundbäck et al. 2006) was $17 \mu \mathrm{mol} \mathrm{N} \mathrm{m} \mathrm{N}^{-2} \mathrm{~h}^{-1}$ for DIN and $72 \mu \mathrm{mol} \mathrm{N} \mathrm{m} \mathrm{N}^{-2} \mathrm{~h}^{-1}$ for DON. These influx rates correspond to only $\sim 30 \%$ of the calculated demand for nitrogen in our experiment when corrected for intact sediment, suggesting that a large part of the demand for nitrogen must be covered by nitrogen remineralized in the sediment. Calculating in situ rates of nitrogen remineralization from oxygen consumption and the C:N content of sediment (Trimmer et al. 2000) resulted in a remineralization rate of $0.5 \mathrm{mmol} \mathrm{m}^{-2} \mathrm{~d}^{-1}$ in April, while the calculated daily microalgal demand at the same time was $>2 \mathrm{mmol} \mathrm{N}$ $\mathrm{m}^{-2} \mathrm{~d}^{-1}$, i.e. far exceeding the mineralization rate of nitrogen (Sundbäck et al. 2006). This further emphasizes the N-limiting conditions of this sandy site in spring and early summer, which was also corroborated by the AMA rates in the present study. In the autumn, however, with much higher remineralization rates $\left(\sim 3 \mathrm{mmol} \mathrm{N} \mathrm{m}^{-2} \mathrm{~d}^{-1}\right)$, the MPB used only $\sim 25$ to $50 \%$ of the available remineralized nitrogen (Sundbäck et al. 2006), reflecting nitrogen-replete conditions in contrast to the situation in spring and early summer.

Even if DON can be an important source of nitrogen for the MPB (accounting for $>50 \%$ of the uptake of nitrogen) in the studied sandy sediment, this amount apparently still does not suffice in the spring and early summer when mineralization rates are still low (Sundbäck et al. 2006). Despite an obvious N-limitation, a high $\mathrm{C}$-fixation by the MPB can be sustained, as was also found by Cook et al. (2007) for a sandy, near-shore sediment. This reflects the fact that $\mathrm{C}$-fixation and the assimilation of nitrogen may not be closely coupled and that a large proportion of the photosynthetic product may be released as DOC, which will be available for bacteria, emphasizing the role of the benthic microbial loop (Goto et al. 1999, Cook et al. 2007, 2009, Böer et al. 2009) under oligotrophic conditions. As suggested earlier (see 'Introduction'), sandy sediments retain nutri- ents efficiently by rapid circulation within the microbial mat, even turning the sediment into a sink during a large part of the year (Sundbäck \& Miles 2000).

The next step in understanding the quantitative role of DON for the MPB would be to combine controlled laboratory experiments on kinetics with simultaneous in situ uptake and flux measurements in different types of intact sediment. More focus should be placed on the composition of the microbial communities (e.g. the ratio between the biomass of primary producers and bacteria, and between eukaryotic and prokaryotic primary producers) because their functional importance can be expected to vary with season and type of sediment. For example, in the sediments of cool microtidal areas, like our site, the proportion of cyanobacteria tends to increase in late summer and autumn. By using biomarkers, such as D-alanine for bacteria, it is now possible to discriminate bacterial and algal uptake (Veuger et al 2007). Knowledge of the composition of the primary producers may be particularly important considering that global change might alter the composition and diversity of microbial communities in shallow-water sediments.

Acknowledgements. Financial support was received from the Royal Society of Arts and Sciences in Gothenburg, the Memorial Fund of Birgit and Birger Wåhlström and the Captain Stenholm Fund (contract holder K.S.), the Swedish Research Council, FORMAS, and 6.3- Global Change and Ecosystem (contract holder E.G.). The authors are very grateful to C. Esplund and P. Holmberg for helping with analyses and sampling. We thank 2 anonymous referees for their most helpful and constructive comments.

\section{LITERATURE CITED}

Admiraal W, Riaux-Gobin C, Laane RWPM (1987) Interactions of ammonium, nitrate, and D- and L-amino acids in the nitrogen assimilation of two species of estuarine benthic diatoms. Mar Ecol Prog Ser 40:267-273

Aertebjerg Nielsen G, Bresta AM (1984) Guidelines for the measurements of phytoplankton primary production. Baltic Marine Biologists, Public No 1, Charlottenlund

Anderson IC, McGlathery KJ, Tyler AC (2003) Microbial mediation of 'reactive' nitrogen transformations in a temperate lagoon. Mar Ecol Prog Ser 246:73-84

> Antia NJ, Harrison PJ, Oliveira L (1991) The role of dissolved organic nitrogen in phytoplankton nutrition, cell biology and ecology. Phycologia 30:1-89

> Aufdenkampe AK, Hedges JI, Richey JE, Krusche AV, Llerena CA (2001) Sorptive fractionation of dissolved organic nitrogen and amino acids onto fine sediments within the Amazon Basin. Limnol Oceanogr 46:1921-1935

> Barranguet C, Kromkamp J, Peene J (1998) Factors controlling primary production and photosynthesis characteristics of intertidal microphytobenthos. Mar Ecol Prog Ser 173:117-126

Billerbeck M, Røy H, Bosselmann K, Huettel M (2007) Benthic phytosynthesis in submerged Wadden Sea intertidal flats. Estuar Coast Shelf Sci 71:704-716 
Böer SI, Arnosti C, van Beusekom JEE, Boetius A (2009) Temporal variations in microbial activities and carbon turnover in subtidal sandy sediments. Biogeosciences 6:1149-1165

Bradley PB, Lomas MW, Bronk DB (2010) Inorganic and organic nitrogen use by phytoplankton along Chesapeake Bay, measured using a flow cytometric sorting approach. Estuar Coast 33:971-984

Bronk DA, See JH, Bradley P, Killberg L (2007) DON as a source of bioavailable nitrogen for phytoplankton. Biogeosciences 4:283-296

Cerco CF, Seitzinger SP (1997) Measured and modeled effects of benthic algae on eutrophication in Indian RiverRehoboth Bay, Delaware. Estuaries 20:231-248

> Chrzanowski TH, Kyle M, Elser JJ, Sterner RW (1996) Element ratios and growth dynamics of bacteria in an oligotrophic Canadian shield lake. Aquat Microb Ecol 11: 119-125

Cook PLM, Revill AT, Butler ECV, Eyre BD (2004) Carbon and nitrogen cycling on intertidal mudflats of a temperate Australian estuary. II. Nitrogen cycling. Mar Ecol Prog Ser 280:39-54

> Cook PLM, Veuger B, Böer S, Middelburg JJ (2007) Effect of nutrient availability on carbon and nitrogen incorporation and flows through benthic algae and bacteria in nearshore sandy sediment. Aquat Microb Ecol 49:165-180

Cook PLM, Van Oevelen D, Soetaert K, Middelburg JJ (2009) Carbon and nitrogen cycling on intertidal mudflats of a temperate Australian estuary. IV. Inverse model analysis and synthesis. Mar Ecol Prog Ser 394:35-48

$>$ de Jonge VN (1980) Fluctuations in the organic carbon to chlorophyll a ratios for estuarine benthic diatom populations. Mar Ecol Prog Ser 2:345-353

Dugdale RC, Goering JJ (1967) Uptake of new and regenerated forms of nitrogen in primary productivity. Limnol Oceanogr 12:196-206

Engelsen A, Hulth S, Pihl L, Sundbäck K (2008) Benthic trophic status and nutrient fluxes in shallow-water sediments. Estuar Coast Shelf Sci 78:783-795

Evrard V, Cook PLM, Veuger B, Huettel M, Middelburg JJ (2008) Tracing carbon and nitrogen incorporation and pathways in the microbial community of a photic subtidal sand. Aquat Microb Ecol 53:257-269

Eyre BD, Ferguson AJP (2005) Benthic metabolism and nitrogen cycling in a subtropical east Australian estuary (Brunswick): temporal variability and controlling factors. Limnol Oceanogr 50:81-96

Eyre BD, Glud RN, Patten N (2008) Mass coral spawning: a natural large-scale nutrient addition experiment. Limnol Oceanogr 53:997-1013

Fenchel T, King GM, Blackburn TH (2000) Bacterial biogeochemistry. The ecophysiology of mineral cycling, 2nd edn. Academic Press, London

> Glibert PM, Burkholder JM, Parrow MW, Lewitus AJ, Gustafson DE (2006) Direct uptake of nitrogen by Pfiesteria piscicida and Pfiesteria shumwayae, and nitrogen nutritional preferences. Harmful Algae 5:380-394

> Goeyens L, Kindermans N, Abu Yusuf M, Elskens M (1998) A room temperature procedure for the manual determination of urea in seawater. Estuar Coast Shelf Sci 47: $415-418$

Goto NTN, Kawamura T, Mitamura O, Teral O (1999) Importance of extracellular organic carbon production in the total primary production by tidal-flat diatoms in comparison to phytoplankton. Mar Ecol Prog Ser 190:289-295

Granéli E, Wallström K, Larsson U, Granéli W, Elmgren R (1990) Nutrient limitation of primary production in the Baltic Sea area. Ambio 19:142-151
Gribsholt B, Veuger B, Tramper A, Middelburg JJ, Boeschker HTS (2009) Long-term ${ }^{15} \mathrm{~N}$ nitrogen retention in tidal freshwater marsh sediment: elucidating the microbial contribution. Limnol Oceanogr 54:13-22

Guldberg LB, Finster K, Jørgensen NOG, Middelboe M, Lomstein B (2002) Utilization of marine sedimentary dissolved organic nitrogen by native anaerobic bacteria. Limnol Oceanogr 47:1712-1722

Harrison PJ, Conway HL, Dugdale RC (1976) Marine diatoms grown in chemostats under silicate and ammonium limitation. I. Cellular chemical composition and steady-state growth kinetics of Skeletonema costatum. Mar Biol 35:177-186

> Hochard S, Pinazo C, Grenz C, Burton Evans JL, Pringault O (2010) Impact of microphytobenthos on the sediment biogeochemical cycles: a modelling approach. Ecol Modell 221:1687-1701

Hoppe HG (1993) Use of fluorogenic model substrates for extracellular enzyme activity (EEA) measurement of bacteria. In: Kemp PF, Sherr BF, Sherr EB, Cole JJ (eds) Handbook of methods in aquatic microbial ecology. Lewis, New York, NY, p 423-431

Jespersen AM, Christoffersen K (1987) Measurements of chlorophyll a from phytoplankton using ethanol as extraction solvent. Arch Hydrobiol 109:445-454

> Jönsson B (1991) A ${ }^{14}$ C-incubation technique for microphytobenthic primary production in intact sediment cores. Limnol Oceanogr 36:1485-1492

Kirchman DL, Wheeler PA (1998) Uptake of ammonium and nitrate by heterotrophic bacteria and phytoplankton in the sub-Arctic Pacific. Deep-Sea Res I 45:347-365

Kühl M, Jørgensen BB (1992) Spectral light measurements in microbenthic phototrophic communities with a fiber-optic microprobe coupled to a sensitve diode array detector. Limnol Oceanogr 37:1813-1823

Lever MA, Valiela I (2005) Response of microphytobenthic biomass to experimental nutrient enrichment and grazer exclusion at different land-derived nitrogen loads. Mar Ecol Prog Ser 294:117-129

> Linares F, Sundbäck K (2006) Uptake of dissolved free amino acids (DFAA) by microphytobenthic communities. Aquat Microb Ecol 42:175-186

Lindehoff E, Granéli E, Glibert PM (2010) Influence of prey and nutritional status on the rate of nitrogen uptake by Prymnesium parvum (haptophyte). J Am Water Resour Assoc 46:121-132

> Lomstein BA, Jensen AGU, Hansen JW, Andreasen JB, Hansen LS, Berntsen J, Kunzendorf H (1998) Budgets of sediment nitrogen and carbon cycling in the shallow water of Knebel Vig, Denmark. Aquat Microb Ecol 14:69-80

> Lorenzen CJ (1967) Determination of chlorophyll and pheopigments: spectrophotometric equations. Limnol Oceanogr 12:343-346

Lorenzen CJ, Jeffrey SW (1980) Determination of chlorophyll in seawater. SCOR-Unesco Tech Pap Mar Sci 35, UNESCO, Paris

> Macko SA, Green EJ (1982) An investigation of the dissolved free amino acids and their relation to phytoplankton cell density in the Damariscotta River estuary, Maine. Estuaries 5:68-73

Martinez J, Smith DC, Steward GF, Azam F (1996) Variability in ectohydrolytic enzyme activities of pelagic marine bacteria and its significance for substrate processing in the sea. Aquat Microb Ecol 10:223-230

> McCarthy JJ, Taylor WR, Taft JL (1977) Nitrogenous nutrition of the plankton in the Chesapeake Bay. 1. Nutrient availability and phytoplankton preferences. Limnol Oceanogr 22:996-1011 
McGlathery K, Sundbäck K, Anderson IC (2007) Eutrophication in shallow coastal bays and lagoons: the role of plants in the coastal filter. Mar Ecol Prog Ser 348:1-18

Middelburg JJ, Niewenhuize J (2000) Nitrogen uptake by heterotrophic bacteria and phytoplankton in the nitraterich Thames estuary. Mar Ecol Prog Ser 203:13-21

> Miles A, Sundbäck K (2000) Diel variation of microphytobenthic productivity in areas with different tidal amplitude. Mar Ecol Prog Ser 205:11-22

Misic C, Harriague AC (2007) Enzymatic activity and organic substrates on a sandy beach of the Ligurian Sea (NW Mediterranean) influenced by anthrophogenic pressure. Aquat Microb Ecol 47:239-251

Mulholland MR, Gobler CJ, Lee C (2002) Peptide hydrolysis, amino acid oxidation, and nitrogen uptake in communities seasonally dominated by Aureococcus anophagefferens. Limnol Oceanogr 47:1094-1108

Mulvenna PF, Savidge G (1992) A modified manual method for the determination of urea in seawater using diacetylmonoxime reagent. Estuar Coast Shelf Sci 34:429-438

Nilsson C, Sundbäck K (1996) Amino acid uptake in natural microphytobenthic assemblages studied by microautoradiography. Hydrobiologia 332:119-129

Nilsson P, Jönsson B, Lindström Swanberg I, Sundbäck K (1991) Response of a shallow-water sediment system to an increased load of inorganic nutrients. Mar Ecol Prog Ser 71:275-290

Paerl HW (1991) Ecophysiological and trophic implications of light-stimulated amino acid utilization in marine picoplankton. Appl Environ Microbiol 57:473-479

Palenik B, Morel FMM (1990) Amino acid utilization by marine phytoplankton: a novel mechanism. Limnol Oceanogr 35:260-269

Parsons R, Maita Y, Lalli CM (1984) A manual of chemical and biological methods for seawater analysis. Pergamon Press, Oxford

Pettersson K, Jansson M (1978) Determination of phosphatase activity in lake water-a study of methods. Verh Int Ver Limnol 20:1226-1230

Ramsing NB, Ferris MJ, Ward DM (2000) Highly ordered vertical structure of Synechococcus populations within the one-millimeter-thick photic zone of a hot spring cyanobacterial mat. Appl Environ Microbiol 66:1038-1049

Risgaard-Petersen N (2003) Coupled nitrification-denitrification in autotrophic and heterotrophic estuarine sediments: On the influence of benthic microalgae. Limnol Oceanogr 48:93-105

Rizzo WM, Dailey SK, Lackey GJ, Christian RR, Berry BE, Wetzel RL (1996) A metabolism-based trophic index for comparing the ecological values of shallow-water sediment habitats. Estuaries 19:247-256

Rondell JB, Finster KW, Lomstein BAa (2000) Urea and DON uptake by a Lyngbya gracilis dominated microbial mat: a controlled laboratory experiment. Aquat Microb Ecol 21: 169-175

Sala MM, Karner M, Arin L, Marrasé C (2001) Measurements of ectoenzyme activities as an indication of inorganic nutrient imbalance in microbial communities. Aquat Microb Ecol 23:301-311

Sundbäck K, Miles A (2000) Balance between denitrification and microalgal incorporation of nitrogen in microbial sediments, NE Kattegat. Aquat Microb Ecol 22:291-300
Sundbäck K, Jönsson B, Nilsson P, Lindström I (1989) Impact of accumulating drifting macroalgae on a shallow-water sediment system: an experimental study. Mar Ecol Prog Ser 58:261-274

Sundbäck K, Nilsson C, Nilsson P, Jönsson B (1996) Balance between autotrophic and hetorotrophic components and processes in microbenthic communities of sandy sediments: a field study. Estuar Coast Shelf Sci 43:689-706

Sundbäck K, Miles A, Hulth S, Pihl L, Engström P, Selander E, Svenson A (2003) Importance of benthic nutrient generation during initiation of macroalgal blooms in shallow bays. Mar Ecol Prog Ser 246:115-126

> Sundbäck K, Linares F, Larson F, Wulff A, Engelsen A (2004) Benthic nitrogen fluxes along a depth gradient in a microtidal fjord: the role of denitrification and microphytobenthos. Limnol Oceanogr 49:1095-1107

Sundbäck K, Miles A, Linares F (2006) Nitrogen dynamics in nontidal littoral sediments: role of microphytobenthos and denitrification. Estuar Coast 29:1196-1211

> Sundbäck K, Alsterberg C, Larson F (2010) Effects of multiple stressors on marine shallow-water sediments: response of microalgae and meiofauna to nutrient-toxicant exposure. J Exp Mar Biol Ecol 388:39-50

Thornton DCO, Dong LF, Underwood GJC, Nedwell DB (2002) Factors affecting microphytobenthic biomass, species composition and production in the Colne Estuary (UK). Aquat Microb Ecol 27:285-300

Trimmer M, Nedwell DB, Sivyer DB, Malcolm SJ (2000) Seasonal organic mineralisation and denitrification in intertidal sediments and their relationship to the abundance of Enteromorpha sp. and Ulva sp. Mar Ecol Prog Ser 203:67-80

> Tuchman NC, Schollet MA, Rier ST, Geddes P (2006) Differential heterotrophic utilization of organic compounds by diatoms and bacteria under light and dark conditions. Hydrobiologia 561:167-177

> Tyler AC, McGlathery KJ, Anderson IC (2003) Benthic algae control fluxes of dissolved organic and inorganic nitrogen fluxes in a temperate coastal lagoon. Limnol Oceanogr 48: 2125-2137

Underwood AJ (1997) Experiments in ecology: their logical design and interpretation using analysis of variance. Cambridge University Press, Cambridge

> Underwood GJC, Kromkamp J (1999) Primary production by phytoplankton and microphytobenthos in estuaries. Adv Ecol Res 29:93-153

Valderrama JC (1995) Methods of nutrient analysis. In: Hallegraeff GM, Anderson DM, Cembella AD (eds) Manual of harmful marine microalgae, IOC Manuals and Guides No 33. Intergovernmental Oceanographic Commission of UNESCO, Paris, p 251-265

Veuger B, Middelburg JJ (2007) Incorporation of nitrogen from amino acids and urea by benthic microbes: role of bacteria versus algae and coupled incorporation of carbon. Aquat Microb Ecol 48:35-46

> Veuger B, Eyre BD, Maher D, Middelburg JJ (2007) Nitrogen incorporation and retention by bacteria, algae, and fauna in a subtropical intertidal sediment: an in situ ${ }^{15} \mathrm{~N}$-labeling study. Limnol Oceanogr 52:1930-1942

> Wawrik B, Callaghan V, Bronk DA (2009) Use of inorganic nitrogen by Synechococcus spp. and diatoms on the West Florida Shelf as measured using stable isotope probing. Appl Environ Microbiol 75:6662-6670

Submitted: July 12, 2010; Accepted: November 25, 2010 Proofs received from author(s): February 14, 2011 